\section{Undergraduate students' experience and self-assessed confidence in prosthetic dentistry}

\section{Mezuniyet öncesi öğrencilerin protetik dişhekimliğindeki tecrübe ve özgüvenleri}

\author{
Assoc. Prof. Zeynep Özkurt-Kayahan \\ Yeditepe University, Faculty of Dentistry, Department of \\ Prosthodontics, Istanbul, Turkey.
}

\section{Prof. İdil Dikbaş}

Yeditepe University, Faculty of Dentistry, Department of Prosthodontics, Istanbul, Turkey

Received : 6 January 2016

Accepted : 29 February 2016

\section{Corresponding author:}

Assoc. Prof. Zeynep Özkurt-Kayahan

Yeditepe University, Faculty of Dentistry

Department of Prosthodontics, Bağdat cad. No: 238

34728, Goztepe, Istanbul, Turkey

Tel: +90 5333269488

Fax: +902163636211

zeynepozkurt@hotmail.com

\section{SUMMARY}

Aim: The aim of this study was to assess the final year students' experience and confidence in prosthetic dentistry within a dental school in Turkey

Materials and Methods: A questionnaire was prepared to assess the students' experience of clinical skills in prosthetic procedures (n:44). Twenty questions were multiple-choice; 1 question was open-ended and 3 questions used a Likerttype scale ranging from 1 (very little confident) to 5 (very confident). The data were statistically analyzed.

Results: Forty percent of the students thought that prosthodontics was the most difficult field in dentistry. Students rated themselves as being least confident in tooth preparation (2.89), making impression for post-core (2.84), determination of occlusal vertical dimension for complete (2.36) and removable partial dentures (2.21), followed by peripheral sealing for complete (2.50) and removable partial dentures (2.32)

Conclusions: There are lots of subjects in which the students reported a lack of confidence that warrants greater emphasis in the undergraduate prosthodontic curriculum.

Key words: Dental student, confidence, experience, prosthodontics.

\section{ÖZET}

Amaç: Bu çalışmanın amacı, Türkiye'deki bir dișhekimliği fakültesinde son sınıf öğrencilerinin protetik diş tedavisindeki tecrübe ve özgüvenlerini değerlendirmektir.

Gereç ve yöntem: Ögrencilerin protetik prosedürlerdeki klinik becerilerini sorgulayan bir anket formu oluşturuldu (n:44). 20 soru çoktan seçmeli, 1 soru açı uçlu ve 3 soru Likert tipi (1-5) skala içerecek şekilde toplamda 24 soruluk formlar oğrencilere dağıııldı. Sonuçlar istatistiksel olarak değerlendirildi.

Bulgular: Öğrencilerin \%40'ı protetik diş tedavisinin dişhekimliğinin en zor alanı olduğunu bildirdi. Öğrenciler kendilerini en çok, diş kesimi (2,89), post ölçüsü alma $(2,84)$, tam protezlerde oklüzal dikey boyut belirleme $(2,36)$, parsiyel protezlerde oklüzal dikey boyut belirleme $(2,21)$, tam protezlerde kenar şekillendirme $(2,50)$ ve parsiyel protezlerde kenar şekillendirme $(2,32)$ sırasında güvensiz hissettiklerini bildirdi.

Sonuç: Protetik diş tedavisi ders müfredatında, oğrencilerin kendilerini yetersiz hissettikleri konular daha fazla vurgulanmalıdır.

Anahtar kelimeler: Diş hekimliği öğrencisi, özgüven, tecrübe, prostodonti. 


\section{INTRODUCTION}

Prosthodontics is one of the indispensable elements of dental fields and is expected to remain so due to the high demand for this type of treatment approach in the population. There are some speculations among dentists and health care planners that tooth loss and edentulism will decrease in the future as a result of improve-ments in preventive dentistry, and an extended lifespan is also expected in the future. ${ }^{1}$ All current prosthodontic services will be needed in the future, because millions of people are still without complete dentitions. If such expectations exist, the importance of knowledge and skills in prosthodontics will continue as the century progresses. ${ }^{3}$ Therefore, dental educators must spend considerable effort in educating their students to meet these continuing needs of patients. ${ }^{4}$

Dental education is regarded as a complicated and stressful procedure. ${ }^{5}$ One of the most critical components of dental education is clinical training. Integrating basic sciences with clinical training is a unique challenge. ${ }^{6}$ The learning environment is a formidable area especially for dental students, because they are expected to be responsible for patient care under their clinical teachers' observation. ${ }^{7}$ The positive learning environment should prepare students for their independent clinical practice life and contribute to their personal development. ${ }^{8}$

The ideal dental curriculum may be defined as one that always renovates itself to the needs of students' and dentistry profession. ${ }^{9}$ Although there are various methods to evaluate the curriculum, assessment of students' experience and confidence is of crucial importance, ${ }^{10}$ and this may improve the undergraduate education provided by the dental schools. ${ }^{11}$ It is likely for final-year dental students to feel unprepared for their future professional life. ${ }^{5}$ Selfconfidence is a significant concern in all phases of dental curriculum, and may be a promoting factor to enter any post-graduate program. ${ }^{12}$ Self-confidence assessment of the students should guide their learning, because they have a realistic sense of their own weaknesses, and they may have the opportunity to focus more on them. This is a perfect approach to increase their self-perceived preparedness for their future practice life. ${ }^{5}$

There are numerous references in the dental literature regarding undergraduate dental students' perceptions of their dental education and preparedness for general dental practice, ${ }^{7-9,11,13-15}$ however, there is no information regarding students' experience and self-assessed confidence about prosthetic dentistry, according to the authors' knowledge. The aim of this study was to evaluate the final-year dental students' self-confidence about their work preparedness in various aspects of prosthetic dentistry prior to graduation in a private dental school in Turkey.

\section{MATERIALS AND METHODS}

Following Institutional Review Board approval, survey data were collected from students near the end of their final year at Yeditepe University, Faculty of Dentistry, Istanbul, Turkey in 2012. There were no identifiers in the survey, and all participations were voluntary. It was stated at the beginning of the survey that all data collected would be kept strictly confidential and the anonymity of the participants was ensured. Prior to filling out the forms, students were informed that they were not obliged to complete and return the questionnaire and the process had no relationship with academic performance or grading. In order to achieve validity and reliability, the survey was conducted on 30 students twice for one week. In the statistical analyses, the Cronbach's alpha value was found as 0.850. In addition, the Cohen's kappa coefficients were greater than 0.7 for each question, hence it was determined that the survey was valid and reliable. Then, the final-year dental students (n:48) were given the survey and completed it anonymously on the last lesson before the final examination. Survey lasted for one course period.

The survey questions were developed by two associate professors in the prosthodontic department who had more than 10 years of experience in the profession. The survey consisted of 2 sections with 24 questions, which were generally directed on students' self-assessment of their preparedness for the post-graduate life. In the first section, 20 questions were multiple-choice, 1 question was openended and inquired about students' opinion on tooth preparation. In the second section, there were 3 questions 
used a Likert-type scale ranging from 1 (very little confident) to 5 (very confident) to record perceived levels of confidence for 3 fields of prosthodontic treatments: complete dentures, removable partial dentures and fixed partial dentures.

\section{RESULTS}

The questionnaires were distributed to 48 students and returned by 44 students (92\% return rate). Twenty-five were females and 19 were males.

\section{Section 1}

Forty percent of the students thought that prosthodontics was the most difficult field in dentistry. Only 7\% of the respondents always had difficulties in prosthetic indications. When respondents were asked to identify their competence on various prosthodontic works, $25 \%$ of them thought that they were competent with the removable partial dentures; and $39 \%$ of them thought that they were competent with the complete dentures, while the majority of them found themselves competent with the fixed partial dentures (64\%) and post-core restorations (59\%). Of the respondents, 77\% could decide if an endodontically treated tooth requires a post-core restoration or not. Half of the respondents thought that endodontists should not prepare the post spaces. The majority of the students had difficulties in preparing maxillary second (79\%) and third molar teeth (96\%). These ratios were $46 \%$ and $78 \%$ for mandibular second and third molar teeth, respectively. The premolars were the types of teeth that posed the least difficulty in terms of tooth preparation (2.3\%). Eighty percent of the students stated that they would consult a specialist about difficult cases in their future clinical practice. Eighty two percent wanted to pursue postgraduate education in prosthodontics.

When respondents were asked to determine the top 3 most difficult cases in clinical practice, 84\% had difficulties with the complete dentures on severely resorbed mandible, $77 \%$ had difficulties with the overage edentulous patients, and 64\% had difficulties with Class III patients who need fixed partial dentures.

Forty five percent of the students found the minimum required number (n:10) of removable dentures (complete and partial) insufficient, and majority of the students thought that minimum number should be 16. However, a high majority stated that the minimum required number of fixed partial dentures and post-core restorations were sufficient (80\% and 93\%, respectively).

\section{Section 2}

The students' confidence levels about different fields of prosthodontic treatments; complete dentures, removable partial dentures and fixed partial dentures, are presented in Table 1, 2 and 3 .

\begin{tabular}{|c|c|c|c|c|c|c|c|c|c|c|c|}
\hline \multirow[t]{2}{*}{ Complete dentures } & \multicolumn{2}{|c|}{$\begin{array}{l}\text { Very confident } \\
5\end{array}$} & \multicolumn{2}{|c|}{$\begin{array}{l}\text { Confident } \\
4\end{array}$} & \multicolumn{2}{|c|}{$\begin{array}{l}\text { Neutral } \\
3\end{array}$} & \multicolumn{2}{|c|}{$\begin{array}{c}\text { Little } \\
\text { confident } \\
2 \\
\end{array}$} & \multicolumn{2}{|c|}{$\begin{array}{c}\text { Very little } \\
\text { confident } \\
1\end{array}$} & \multirow[t]{2}{*}{ Mean } \\
\hline & $n$ & $\%$ & $n$ & $\%$ & $n$ & $\%$ & $n$ & $\%$ & $n$ & $\%$ & \\
\hline first impression (alginate) & 20 & 45.5 & 18 & 40.9 & 4 & 9.1 & 2 & 4.5 & 0 & 0 & 4.27 \\
\hline $\begin{array}{l}\text { evaluating the suitability of individual } \\
\text { impression tray }\end{array}$ & 11 & 25 & 24 & 54.5 & 7 & 15.9 & 1 & 2.3 & 1 & 2.3 & 3.97 \\
\hline $\begin{array}{l}\text { peripheral sealing with impression } \\
\text { compound }\end{array}$ & 2 & 4.5 & 5 & 11.4 & 13 & 29.5 & 17 & 38.6 & 7 & 15.9 & 2.5 \\
\hline final impression (zincoxide-eugenol) & 0 & 0 & 9 & 20.5 & 21 & 47.7 & 4 & 9.1 & 10 & 22.7 & 2.65 \\
\hline arranging the occlusion rims & 0 & 0 & 7 & 15.9 & 20 & 45.5 & 12 & 27.3 & 5 & 11.4 & 2.65 \\
\hline determination of vertical dimension & 0 & 0 & 3 & 6.8 & 19 & 43.2 & 13 & 29.5 & 9 & 20.5 & 2.36 \\
\hline face-bow transfer & 0 & 0 & 16 & 36.4 & 17 & 38.6 & 8 & 18.2 & 3 & 6.8 & 3.04 \\
\hline centric relation record & 0 & 0 & 11 & 25 & 13 & 29.5 & 13 & 29.5 & 7 & 15.9 & 2.63 \\
\hline try-in & 6 & 13.6 & 17 & 38.6 & 18 & 40.9 & 3 & 6.8 & 0 & 0 & 3.59 \\
\hline delivery of the denture to the patient & 7 & 15.9 & 26 & 59.1 & 7 & 15.9 & 3 & 6.8 & 1 & 2.3 & 3.79 \\
\hline follow-up services & 10 & 22.7 & 26 & 59.1 & 7 & 15.9 & 1 & 2.3 & 0 & 0 & 4.02 \\
\hline
\end{tabular}

Table 1: Self-assessed confidence levels of students about complete dentures 


\begin{tabular}{|c|c|c|c|c|c|c|c|c|c|c|c|}
\hline \multirow[t]{2}{*}{ Removable partial dentures } & \multicolumn{2}{|c|}{$\begin{array}{l}\text { Very confident } \\
5\end{array}$} & \multicolumn{2}{|c|}{$\begin{array}{l}\text { Confident } \\
4\end{array}$} & \multicolumn{2}{|c|}{$\begin{array}{c}\text { Neutral } \\
3\end{array}$} & \multicolumn{2}{|c|}{$\begin{array}{c}\text { Little } \\
\text { confident } \\
2\end{array}$} & \multicolumn{2}{|c|}{$\begin{array}{c}\text { Very little } \\
\text { confident } \\
1\end{array}$} & \multirow[t]{2}{*}{ Mean } \\
\hline & $n$ & $\%$ & $n$ & $\%$ & $n$ & $\%$ & $n$ & $\%$ & $n$ & $\%$ & \\
\hline first impression (alginate) & 14 & 35 & 22 & 55 & 4 & 10 & 0 & 0 & 0 & 0 & 3.68 \\
\hline $\begin{array}{c}\text { preparation of rest seat and guiding } \\
\text { planes }\end{array}$ & 1 & 2.5 & 10 & 25 & 20 & 50 & 6 & 15 & 0 & 0 & 2.66 \\
\hline $\begin{array}{l}\text { evaluating the suitability of individual } \\
\text { impression tray }\end{array}$ & 3 & 7.5 & 20 & 50 & 12 & 30 & 3 & 7.5 & 0 & 0 & 3.11 \\
\hline $\begin{array}{l}\text { peripheral sealing with impression } \\
\text { compound }\end{array}$ & 1 & 2.5 & 3 & 7.5 & 19 & 47.5 & 11 & 27.5 & 6 & 15 & 2.32 \\
\hline final impression (alginate) & 5 & 11.4 & 17 & 38.6 & 11 & 25 & 4 & 9.1 & 3 & 6.8 & 3.11 \\
\hline framework evaluation & 1 & 2.5 & 11 & 27.5 & 23 & 57.5 & 4 & 10 & 1 & 2.5 & 2.89 \\
\hline arranging the occlusion rims & 0 & 0 & 8 & 18.2 & 17 & 38.6 & 12 & 27.3 & 3 & 6.8 & 2.5 \\
\hline determination of vertical dimension & 0 & 0 & 4 & 10 & 14 & 35 & 17 & 42.5 & 5 & 12.5 & 2.21 \\
\hline face-bow transfer & 1 & 2.5 & 11 & 27.5 & 18 & 45 & 8 & 20 & 2 & 5 & 2.75 \\
\hline centric relation record & 0 & 0 & 5 & 12.5 & 17 & 42.5 & 12 & 30 & 6 & 15 & 2.29 \\
\hline try-in & 0 & 0 & 21 & 52.5 & 16 & 40 & 1 & 2.5 & 2 & 5 & 3.09 \\
\hline delivery of the denture to the patient & 5 & 12.5 & 24 & 60 & 9 & 22.5 & 0 & 0 & 2 & 4.5 & 3.41 \\
\hline follow-up services & 9 & 22.5 & 19 & 47.5 & 11 & 25 & 0 & 0 & 1 & 2.5 & 3.52 \\
\hline
\end{tabular}

Table 2: Self- assessed confidence levels of students about removable partial dentures

\begin{tabular}{|c|c|c|c|c|c|c|c|c|c|c|c|}
\hline \multirow[t]{2}{*}{ Fixed partial dentures } & \multicolumn{2}{|c|}{ Very confident } & \multicolumn{2}{|c|}{$\begin{array}{l}\text { Confident } \\
4\end{array}$} & \multicolumn{2}{|c|}{$\begin{array}{c}\text { Neutral } \\
3\end{array}$} & \multicolumn{2}{|c|}{$\begin{array}{c}\text { Little } \\
\text { confident } \\
2 \\
\end{array}$} & \multicolumn{2}{|c|}{$\begin{array}{c}\text { Very little } \\
\text { confident } \\
1\end{array}$} & \multirow[t]{2}{*}{ Mean } \\
\hline & $n$ & $\%$ & $n$ & $\%$ & $n$ & $\%$ & $n$ & $\%$ & $n$ & $\%$ & \\
\hline removing the existing crowns/bridges & 6 & 13.6 & 12 & 27.3 & 18 & 40.9 & 7 & 15.9 & 1 & 2.3 & 3.34 \\
\hline tooth preparation & 3 & 6.8 & 4 & 9.1 & 25 & 56.5 & 9 & 20.5 & 3 & 6.8 & 2.89 \\
\hline retraction cord insertion & 3 & 6.8 & 10 & 22.7 & 17 & 38.6 & 10 & 22.7 & 4 & 9.1 & 32.5 \\
\hline $\begin{array}{l}\text { first impression (heavy body } \\
\text { elastomeric material) }\end{array}$ & 2 & 4.5 & 14 & 31.8 & 24 & 54.5 & 3 & 6.8 & 1 & 2.3 & 3.3 \\
\hline $\begin{array}{c}\text { second impression (light body } \\
\text { elastomeric material) }\end{array}$ & 1 & 2.3 & 14 & 31.8 & 23 & 52.3 & 5 & 11.4 & 1 & 2.3 & 3.2 \\
\hline interocclusal record & 4 & 9.1 & 22 & 50 & 13 & 29.5 & 4 & 9.1 & 1 & 2.3 & 3.55 \\
\hline temporary crown construction & 1 & 2.3 & 9 & 20.5 & 21 & 47.7 & 11 & 25 & 2 & 4.5 & 2.91 \\
\hline metal try-in & 2 & 4.5 & 27 & 61.4 & 14 & 31.8 & 0 & 0 & 1 & 2.3 & 3.75 \\
\hline shade selection & 5 & 11.4 & 21 & 47.7 & 14 & 31.8 & 3 & 6.8 & 1 & 2.3 & 3.59 \\
\hline porcelain try-in \& occlusion control & 3 & 6.8 & 13 & 29.5 & 21 & 47.7 & 6 & 13.6 & 1 & 2.3 & 3.25 \\
\hline cementation & 6 & 13.6 & 26 & 59.1 & 9 & 20.9 & 3 & 6.8 & 0 & 0 & 3.93 \\
\hline post space preparation & 2 & 4.5 & 16 & 36.4 & 14 & 31.8 & 11 & 25 & 1 & 2.3 & 3.16 \\
\hline making impression for post-core & 1 & 2.3 & 9 & 20.5 & 19 & 43.2 & 12 & 27.3 & 3 & 6.8 & 2.84 \\
\hline try-in of post-core & 4 & 9.1 & 26 & 59.1 & 10 & 22.7 & 2 & 4.5 & 2 & 4.5 & 3.64 \\
\hline cementation of post-core & 9 & 20.5 & 24 & 54.5 & 9 & 20.5 & 1 & 2.3 & 1 & 2.3 & 3.89 \\
\hline
\end{tabular}

Table 3: Self- assessed confidence levels of students about fixed partial dentures 


\section{DISCUSSION}

Unlike other special areas of dental practice, the heart of the dental profession has been prosthetic dentistry, which is performed by general dentists. ${ }^{16}$ Presently, there is considerable need and demand for extensive prosthodontic services and the need has been projected to grow. The demand for prosthetic treatments would likely increase in the future, particularly with the increased usage of new materials and treatment modalities. The objective of any prosthodontic service is to restore the patient to normal function, contour, esthetics, speech, and health. The key to success is a thorough diagnosis, understanding the patient's desires and expectations, and following a standardized sequence of treatment. ${ }^{17}$

The goal of the dental school is to prepare dental students to practice dentistry. ${ }^{18}$ Currently, there is growing trend in Turkey to open new dental schools, due to the increasing popularity of the dentistry profession. Therefore, revision of educational programs and updating dental education curriculum are necessary to be compatible with other dental faculties in developed countries. ${ }^{19}$ One method to assess a curriculum recommended by educators is to evaluate the students' self-reported confidence, whether they are adequately prepared for the prosthodontic portion of their dental practice. ${ }^{18,20}$ Accurate self-assessment is an important attribute to develop in dental students. ${ }^{20}$ There are several studies which investigated the dental students' perceptions of their dental education, ${ }^{7,9,11,13}$ self-perceived preparedness for general dental practice, 8,14,15 and students' evaluation of their prosthodontic curriculum. ${ }^{18}$ The results of this study report the final year dental students' experience and self-reported confidence when performing prosthetic procedures at Yeditepe University Faculty of Dentistry. The high response rate (92\%) is satisfactory to draw a general conclusion on the dental school's general condition.

Prosthodontics was the most difficult field in dentistry according to $40 \%$ of the students. On the other hand, $82 \%$ of the respondents wanted to pursue post-graduate education in prosthodontics, and $80 \%$ stated that they would consult to a specialist in difficult cases in their future clinical practice. These results may be related to the extensive area of the field. There are lots of topics that prosthetic dentistry includes such as; fixed prosthodontics, removable prosthodontics, temporomandibular disorders, implant prosthesis, maxillofacial prosthesis and gerodontology. ${ }^{18}$ Although students are not responsible of performing clinical procedures of all prosthodontic topics during their education, they are provided with didactic knowledge regarding the basic principles of these topics.
The majority of the students (70\%) stated that they occasionally had difficulties in prosthetic indications. Only $7 \%$ of them indicated that they always experienced difficulty. The reason for such a result may be the integrated clinic where the students provide patient care, which is not limited to only one single discipline. The students have the opportunity to disperse the clinical period to any type of treatment necessary for the patients. They probably learn overall evaluation of the cases in this type of clinical design and perform all required treatments including endodontic, periodontal and minimal invasive surgical treatments. Completing a patient care from diagnosis to delivery of the prosthesis under their experienced clinical teachers' supervision appears to be beneficial for their prosthetic practices in the future.

A positive learning environment should focus on learning, rather than performance. The students are accustomed to focus only on examinations, higher grades and completion of the requirements for graduation. ${ }^{5}$ In the last few years, the total number of patients treated by the students has decreased in Yeditepe University. Although the learning curve of each individual may differ, there should still be a minimum threshold clinical experience for a dental student to be deemed competent. Besides, the quality of patient care including diagnosis, treatment planning, decision making, pre-prosthetic mouth preparation, and laboratory and clinical skills are also crucial factors. In the present study, $45 \%$ of the students believed the minimum number (n:10) of removable dentures (complete and partial) required for graduation was inadequate, and they thought it should be increased to 16. A high majority (80-93\%) stated that the minimum required number of fixed partial dentures and postcore restorations were adequate, respectively. Any further reductions in requirements may significantly compromise educational quality. Furthermore, when the competence of students was evaluated, fixed prosthodontics was among the topics for which they believed they were best prepared (64\%), while they were least prepared for removable partial dentures (25\%). They also regarded themselves as being well prepared for post-core restorations (59\%), and 77\% indicated that they could decide if an endodontically treated tooth requires a post-core or not. This may be explained by the initiation of practices with removable dentures during the inexperienced phase of their educational lives. Fixed partial dentures and post-cores may appear easier as they acquire more competence, and their manipulative skills progress throughout the education. Therefore, it is likely that they consider the required number for fixed partial dentures and post-cores as adequate, and believe they are competent in these fields. 
Another finding of the present study was that students had difficulties in preparing maxillary second and third molars (79\%, 96\%), and mandibular second and third molars (46\%, 78\%). This is an expected finding due to the location of these teeth. Limited degree of mouth opening is also a contributing factor on the difficulty of molar tooth preparation. Development of skills in terms of molar tooth preparation including difficult cases with limited mouth opening and/or tilted molars should be given priority by faculty in order to report higher levels of confidence in the future.

When respondents were asked to determine the top 3 most difficult edentulous cases in clinical practice, 84\% thought that the most difficult procedure was complete denture on severely resorbed mandible. The achievement of optimum denture stability is difficult for conventional complete dentures due to a lack of predictable outcome and variation in the patient's ability to adapt to complete dentures especially in the mandible. ${ }^{21}$ Recently, the trend toward implant prostheses has increased in edentulous patients; however, this treatment can be out of reach for patients who fail to qualify or those who do not have sufficient resources to afford it. ${ }^{22}$ Another solution is the neutral zone concept that implies acquired muscle control by tongue, lips, and cheeks toward the denture stability. By employing the neutral zone concept, the dislodging muscle energy can easily become a retentive and stabilizing force, especially for mandibular complete dentures. ${ }^{23}$ Both treatment approaches are not included in undergraduate clinical education. In addition, $77 \%$ of respondents had difficulties with the overage edentulous patients. This is probably the most difficult group of edentulous patients to manage. In the elderly, the physiological state reduces patients' ability to adapt to oral rehabilitation and degrades the patient's oral condition. ${ }^{24}$ Furthermore, these patients also frequently have a larger number of medical problems. ${ }^{25}$

Among the respondents, $64 \%$ had difficulties in patients with Class III malocclusion who need fixed partial dentures. Although undergraduate students do not treat patients with severe Class III malocclusion who need complicated treatments, including orthodontics and prosthodontics, they can make short-span bridges. The main complaints of these patients are masticatory difficulty and poor esthetics. The clinician must understand how the malocclusion affects the patient esthetically, functionally, and biologically. Prosthetic rehabilitation may be indicated to establish an acceptable occlusal vertical dimension, and prosthodontic approach using fixed restorations can provide exceptional strength, function and esthetics. ${ }^{26}$ This type of treatment is the topic of post-graduate prosthodontic education.

The scoring regarding self-confidence levels of various aspects of prosthetic dentistry revealed that, determination of occlusal vertical dimension (OVD) both for complete (2.36) and removable partial dentures (2.21) was the area where students felt the lowest confidence followed by peripheral sealing with impression compound for complete (2.50) and removable partial dentures (2.32). Determining appropriate OVD in the treatment of the edentulous patient is an important but critical procedure in practice. Incorrect determination of the OVD may result in failure of complete denture treatment. Although various methods including physiologic rest position, swallowing, phonetics, esthetic and extra-oral measurements for determining OVD have been described, establishing an appropriate vertical dimension remains challenging. There is no single precise scientific method for determining the correct OVD. ${ }^{27}$ Students enrolled in Yeditepe University use extraoral measurements, Niswonger technique, phonetics and esthetics for establishing the OVD. ${ }^{28}$ Determining of OVD is related to clinical experience of dentists, and clinical sense with respect to this ability also develops as time progresses.

Students rated themselves as being least confident in tooth preparation (2.89) for fixed prosthodontics. This may be related to minimal clinical experience, visual errors or anatomic variations. The form of prepared teeth and the amount of tooth structure removed are important contributors to the mechanical, biological and esthetic success of the fixed dental prosthesis. Clinical guidelines should be developed to optimize success in fixed prosthodontics. ${ }^{29}$ Another area in which the students reported low levels of confidence was the making impression for post-core (2.84). This may be explained by limited area of the post spaces, limited view of the impression area or necessity of an assistant during making impression for post-core. Students enrolled in Yeditepe University use indirect technique, a valuable technique for the dental practitioners, ${ }^{30}$ to fabricate a cast post-core. Development of skills in terms of making impression for post-core may be given priority by educators, or direct impression technique for post-core may be emphasized in which the students can perform independently.

The limitations of the present study is that only one school is included where the study was conducted on a group of students, and definitely reflects the opinions of only a limited group. Future studies performed in different dental schools 
with higher sample size that focus on various aspects of prosthodontic education will be supportive in developing strategies to deliver the best information to dental students.

\section{CONCLUSIONS}

This is the first study about students' self assessment on prosthodontic program conducted in a Turkish dental school. To evaluate the difficulty of prosthetic dentistry successfully prior to graduation, students' perception should be taken into account. Not only would this help to improve the curriculum, but it would also increase students' level of confidence with their future clinical practice. According to results, it can be clearly observed that dental students do not feel themselves well prepared regarding some clinical topics, such as removable partial dentures. Educators should determine major missing areas that need further improvement, and give priority to enhance the way information and experience regarding these topics are conveyed. The authors suggest that this survey should be conducted in other Turkish dental schools to determine the overall country situation and to make comparison between them. 


\section{REFERENCES}

1. Douglass CW, Watson AJ. Future needs for fixed and removable partial dentures in the United States: J Prosthet Dent 2002;87:9-14

2. Goodacre CJ. Predoctoral fixed prosthodontics education. J Prosthet Dent 1990;64:319-25.

3. Lang BR. A review of traditional therapies in complete dentures. J Prosthet Dent 1994;72(5):538-42.

4. Lang LA, Holmes DC, Passon C, Trombly RM, Astroth JD, Tavel AF. Introducing dental students to clinical pa-tient care: the complete denture prosthodontics transition clinic. J Prosthodont 2003:12:206-10.

5. Divaris K, Barlow PJ, Chendea SA, Cheong WS, Dounis A, Dragan IF, Hamlin J, Hosseinzadeh L, Kuin D, Mitrirattanakul S, Mo'nes M, Molnar N, Perryer G, Pickup J, Raval N, Shanahan D, Songpaisan Y, Taneva E, Yaghoub-Zadeh S, West K, Vrazic D. The academic environment: the students' perspective. Eur J Dent Educ 2008;12 Suppl 1:120-30

6. Valachovic RW. Making science clinically relevant. J Dent Educ 1997:61:434-6.

7. Gerzina TM, McLean T, Fairley J. Dental clinical teaching perceptions of students and teachers. J Dent Educ 2005:69:1377-84.

8. Manakil J, George R. Self-perceived work preparedness of the graduating dental students. Eur J Dent Educ 2013:17(2):101-5.

9. Shetty VB, Shirahatti RV, Pawar P. Students' perceptions of their education on graduation from a dental school in India. J Dent Educ 2012:76:1520-6.

10. Henzi D, Davis E, Jasinevicius R, Hendricson W. In the students' own words: what are the strengths and weaknesses of the dental school curriculum? J Dent Educ 2007:71:632-45.

11. Nicolas E, Baptiste M, Roger-Leroi V. Clermont-Ferrand dental school curriculum: an appraisal by last-year students and graduates. Eur J Dent Educ 2009;13:93-9.

12. Polychronopoulou A, Divaris K. Perceived sources of stress among Greek dental students. J Dent Educ 2005;69:687-92

13. Cardall WR, Rowan RC, Bay C. Dental education from the students' perspective: curriculum and climate. $J$ Dent Educ 2008;72:600-9.

14. Honey J, Lynch CD, Burke FM, Gilmour AS. Ready for practice? A study of confidence levels of final year dental students at Cardiff University and University College Cork. Eur J Dent Educ 2011;15:98-103.

15. Yiu CK, McGrath C, Bridges S, Corbet EF, Botelho MG, Dyson JE, Chan LK. Self-perceived preparedness for dental practice amongst graduates of The University of Hong Kong's integrated PBL dental curriculum. Eur J Dent Educ 2012:16:e96-e105.

16. McGivney GP. Advanced education in prosthodontics. J Prosthet Dent 1990;64:334-41

17. Duncan JP, Taylor TD. Simplified complete dentures. Dent Clin North Am 2004:48:625-40

18. Haug SP, Brown DT, Goodacre CJ, Cerimele BJ. Recent graduates' and current dental students' evaluation of their prosthodontic curriculum. J Prosthet Dent 1993;70:361-71

19. Dikbas I, Ozkurt Z, Kazazoglu E. Predoctoral prosthodontic curricula on removable partial dentures: survey of Turkish dental schools. J Dent Educ 2013;77:85-92

20. Curtis DA, Lind SL, Dellinges M, Setia G, Finzen FC. Dental students' self-assessment of preclinical examinations. J Dent Educ 2008;72:265-77.

21. Panek H, Krawczykowska H, Dobosz A, Napadlek P. Panek BA, Sosna-Gramza M. Follow-up visits as a measure of adaptation process to removable prostheses. Gerodontology 2006,23:87-92.

22. Salinas TJ.Treatment of edentulism: optimizing outcomes with tissue management and impression techniques. J Prosthodont 2009; 18:97-105.

23. Beresin VE, Schiesser FJ. The neutral zone in complete dentures. J Prosthet Dent 2006;95(2):93-100.

24. Ivanhoe JR, Cibirka RM, Parr GR. Treating the modern complete denture patient: a review of the literature. $J$ Prosthet Dent 2002:88:631-5.

25. Quirino MR, Birman EG, Paula CR. Oral manifestations of diabetes mellitus in controlled and uncontrolled patients. Braz Dent J 1995;6:131-6.

26. Sakar O, Beyli M, Marsan G. Combined prosthodontic and orthodontic treatment of a patient with a Class III skeletal malocclusion: a clinical report. J Prosthet Dent 2004:92: 224-8.

27. Mays KA. Reestablishing occlusal vertical dimension using a diagnostic treatment prosthesis in the edentulous patient: a clinical report. J Prosthodont 2003;12:30-6.

28. Ozkurt Z, Dikbas I, Kazazoglu E. Predoctoral prosthodontic curriculum forcomplete dentures: survey in Turkish dental schools. J Dent Educ 2013;77:93-8.

29. Goodacre CJ. Designing tooth preparations for optimal success. Dent Clin N Am 2004:48: 359-85.

30. Pitigoi-Aron G, Streacker AB, Schulze KA, Geissberger $M$. Accuracy of cast posts and cores using a new investigative method. Gen Dent 2012;60:e153-7. 